\title{
Antiproliferative Effect of Crude Venom from Conus virgo on Human Lung Cancer Cell Line and Toxicity Assessment on Adult Zebra Fish (Danio rerio)
}

\author{
Dhana Sekaran Ganesan, Mohamed Asik Raj Mohamed, Pema Lhanzin, Kathirvel Neelan, \\ Lakshmanan Vadakkuvaselvi, Sellamuthu Subramani, Arulvasu Chinnasamy*
}

Unit of Animal Tissue Culture and Aquaculture, Department of Zoology, University of Madras, Guindy Campus, Chennai,

Tamil Nadu, INDIA.

\begin{abstract}
Background: For the past two decades, few conotoxins entered in clinical trial and some are available for pain relieving as well as for treatment of neurological disorders. Aim: The present investigation was made to elucidate the antiproliferative effect of crude venom from Conus virgo against human lung adenocarcinoma cells. Acute toxicity was determined on adult Zebra fish. Methods: Cytotoxicity was assessed by MTT assay where the DNA damage was carried out by DNA fragmentation method and the in vivo toxicity was assessed by OECD guidelines. Results: The cell viability was found to decrease and the cell lost their morphological integrity with increasing concentration $(10,20,30,40,50,60,70,80,90$ and $100 \mu \mathrm{g} / \mathrm{ml})$ with an $\mathrm{IC}_{50}$ concentration of $74.69 \mu \mathrm{g} / \mathrm{ml}$. The nuclear integrity and DNA fragmentation assay revealed the induction of DNA damage which was observed at $5 \mathrm{~h}$. Further acute toxicity study was made, the $\mathrm{LD}_{50}$ was found at a concentration of $96.393 \mu \mathrm{g} / \mathrm{ml}$. The crude venom affects the locomotory activity of adult Zebra fish and induces the paralytic activity at 50, 75, 100 and $125 \mu \mathrm{g} / \mathrm{ml}$ concentrations. Histology of brain tissue indicated slight variations in the pallium. Conclusion: From the investigation, it was inferred that $C$. virgo venom could be a potential candidate for cancer chemotherapy.
\end{abstract}

Key words: A549, Conus virgo, Cone snail, Zebra fish, Acute toxicity.

\section{INTRODUCTION}

Many organisms from bacteria to higher organisms are capable of producing venom. Venom possesses many biological activity and they are either peptides or non-peptides. It serves to kill a prey, to digest it or to defend against a predator. It possesses various pharmacological applications according to its composition. ${ }^{1}$ Many invertebrates including spiders, centipedes, scorpions, caterpillars, bees, wasps, some snails, jellyfishes and vertebrates such as puffer fishes, frogs and many snakes have venom for their feeding and protection. ${ }^{2}$ Among these poisonous or venomous animals, one of the largest group of species has a great venom pattern coming under the phylum mollusca and class gastropoda. The venom of cone snail is of a complex mixture with 50 to 200 different peptides with each containing only 10 to 35 amino acids in length, which is distinct from each species. ${ }^{3}$ These toxins act as a combination of drug strategy or a 'cabal', by first immobilising the prey then disrupting its neuromuscular transmission. ${ }^{4}$ The conotoxin are under investigation of some disease which includes chronic pain, epilepsy, cardiovascular disease, psychiatric disorder, movement disorder, spasticity, cancer and stroke. $^{5}$

Cancer is one of the chief public health problems worldwide and is the second leading cause of death. ${ }^{6}$ Cancer is responsible for approximately $13 \%$ of death worldwide. In 2015, 8.8 million people worldwide died
Submission Date: 28-02-2019; Revision Date: 24-05-2019; Accepted Date: 16-10-2019

DOI: 10.5530/ijper.54.1.10 Correspondence: Dr. Chinnasamy Arulvasu, Assistant Professor, Department of Zoology, University of Madras, Guindy campus, Chennai-25, Tamil Nadu, INDIA. Phone: +91-044-22202836 E-mail: carulvasu@gmail. com

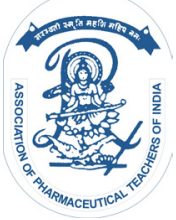

www.ijper.org 
from cancer. In India about 14.3 lakhs new cancer cases were expected during 2016. These numbers are in increasing trend in the past 5 years. ${ }^{7}$ Among the different types of cancers known lung cancer is the second most common cancer in the world. It is responsible for more than one million deaths each year. ${ }^{8}$ The Male populations are mostly affected than female population. In India $6.9 \%$ of new cancer cases and $9.3 \%$ of lung cancer were reported. ${ }^{6}$ Hence there is a need to search for new therapeutic molecules from natural source which effectively target the cancer cell. Therefore the present study was aimed to investigate the crude venom isolated from Conus virgo against the human lung cancer cell (A549) and the acute toxicity was assessed on adult Zebra fish.

\section{MATERIALS AND METHODS}

\section{Collection and identification of cone snail}

The cone snails were collected from South East Cost of Tamil Nadu near Kasimedu, Chennai, India and were carefully transported to the laboratory. It was stored at $-4^{\circ} \mathrm{C}$ until use. The Conus virgo was identified based on the morphological key characters as explained. ${ }^{9}$

\section{Isolation of crude venom from Conus virgo}

The isolation of crude venom from $C$. virgo was done by the method. ${ }^{10}$

\section{Quantitative and Qualitative analysis of crude venom from Conus virgo}

The total protein present in the venom of $C$. virgo was quantified by the method, ${ }^{11}$ the protein profile of crude venom from $C$. virgo was analyzed using $10 \%$ Native-poly acrylamide gel electrophoresis (NativePAGE) according to the method. ${ }^{12}$

\section{Cancer cell line and chemicals}

Lung cancer line (A549) was obtained from NCCS, Pune, India. Dulbecco's modified eagle medium (DMEM), Trypsin-EDTA, Fetal Bovine Serum (FBS), 3-(4, 5dimethylthiazol-2yl)-2, 5- diphenyltetrazolium bromide (MTT), sodium bicarbonate, Dimethyl sulphoxide (DMSO) and antibiotic solution were purchased from Hi media laboratories, Mumbai, India. 96 well plates, 6 well plates, Tissue culture flasks (25 and $75 \mathrm{~mm}^{2}$ ), Centrifuge tubes $(15$ and $50 \mathrm{ml})$ were purchased from Tarsons products Pvt, Kolkata, India. Chemicals used in the present study were highest quality available locally.

\section{Cell viability assay}

The cell viability was assessed by MT'T assay. ${ }^{13}$ Briefly, A549 cells $\left(5 \times 10^{3}\right.$ cells $\left./ \mathrm{ml}\right)$ were plated in 96 well plates with DMEM medium containing 10\% FBS. The cells were incubated for $24 \mathrm{~h}$ under $5 \% \mathrm{CO}_{2}, 95 \% \mathrm{CO}_{2}$ at $37^{\circ} \mathrm{C}$. The medium was removed and washed with PBS. The control cells received serum free medium and treatment cells received 10, 20, 30, 40, 50, 60, 70, 80, 90 and $100 \mu \mathrm{g} / \mathrm{ml}$ of the crude of venom along with medium. Then the cultures plates were again incubated as above. After $24 \mathrm{~h}, 10 \mu \mathrm{l}$ of MTT stock solution was added to each well and the cultures were further incubated for $3 \mathrm{~h}$ and the supernatant was decanted. $100 \mu \mathrm{l}$ DMSO was added and the formed crystal was dissolved gently by pipetting 2 to 3 times. An absorbance at $570 \mathrm{~nm}$ was read at micro plate reader. Growth inhibition rate was calculated as follows:

$$
\text { Percentage of growth inhibition }=\frac{A_{570} \text { of treated cells }}{A_{570} \text { of control cells }} \times 100
$$

\section{Cell morphological study}

The general cell morphological changes of crude venom treated A549 cancer cell line was observed under light microscopic visualization. The A549 $\left(5 \times 10^{4}\right.$ cells $\left./ \mathrm{ml}\right)$ were plated in 6 well plates with DMEM medium containing $10 \% \mathrm{FBS}$ and was maintained as above. The medium was removed and the control dishes received again fresh medium and the treatment dishes received 30 and $80 \mu \mathrm{g} / \mathrm{ml}$ of crude venom. The culture plates were incubated as above. After the incubation time the cells were visualized and photographed under inverted light microscope (Radical) at 20X magnification.

\section{Propidium iodide staining}

The Nuclear morphological changes were observed by the method. ${ }^{14}$ A549 cells were seeded in 6 well plates maintained as above as mentioned in cytomorphological observation. After completion of incubation time the cells were washed with PBS and fixed in methanol: acetic acid $(3: 1 \mathrm{v} / \mathrm{v})$ for $10 \mathrm{~min}$ and stained with $50 \mu \mathrm{g} / \mathrm{ml}$ of propidium iodide for $20 \mathrm{~min}$. After staining the cells were visualized immediately under florescence microscope (Radical) at 40X magnification.

\section{Analysis of DNA-fragmentation}

The DNA fragmentation analysis was carried out by the method. ${ }^{14}$ Cancer cells $\left(3 \times 10^{6}\right.$ cells $\left./ \mathrm{ml}\right)$ were plated in petri dish and maintained under $5 \% \mathrm{CO}_{2}, 95 \% \mathrm{O}_{2}$ at $37^{\circ} \mathrm{C}$. The control wells received medium alone whereas the treated wells received 10 and $100 \mu \mathrm{g} / \mathrm{ml}$ concentration of crude venom along with medium. Then the cultures plates were again incubated as above mentioned. After completion of incubation time, the DNA was extracted from the cell lysate by phenol 
chloroform method as follows. The cells were washed with PBS and then fresh $0.5 \mathrm{ml}$ of lysis buffer was added. The lysates was transferred to a microfuge tube and incubated for $1 \mathrm{~h}$ at $37^{\circ} \mathrm{C}$. To this, $4 \mu \mathrm{l}$ of proteinase $\mathrm{K}$ was added and the tubes were incubated at $50^{\circ} \mathrm{C}$ for $3 \mathrm{~h}$. To each tube, $0.5 \mathrm{ml}$ of phenol : chloroform : isoamyl alcohol $(25: 24: 1)$ was added and mixed and then centrifuged at $10,000 \mathrm{rpm}$ for $10 \mathrm{~min}$ to separate the DNA containing upper aqueous phase. Phenolchloroform extraction was repeated twice, followed by chloroform extraction alone. To the resulting aqueous phase, 2 volumes of ice-cold absolute ethanol and $1 / 10^{\text {th }}$ volume of $3 \mathrm{M}$ sodium acetate were added and incubated for $30 \mathrm{~min}$ on ice to precipitate DNA. DNA was pelleted by centrifuging at 3,000 rpm for $10 \mathrm{~min}$ at $4^{\circ} \mathrm{C}$, the supernatant was aspirated and the pellet was washed with $1 \mathrm{ml}$ of $70 \%$ ethanol. After repeating the above centrifugation step, the last traces of the supernatant fraction was removed by allowing the pellet to dry at room temperature for approximately $30 \mathrm{~min}$ and then it was re-suspended in $50 \mu$ l of TAE buffer. The DNA was quantified by UV-visible spectroscopy and $10 \mu \mathrm{g}$ of DNA was separated by agarose gel electrophoresis in a $1 \%$ agarose gel containing ethidium bromide in a mini gel tank containing TBE buffer for $1 \mathrm{~h}$ under $90 \mathrm{~V}$. Then the gel was examined under UV transilluminator (Biorad) and it was then photographed.

\section{Collection and maintenance of experimental animals}

The adult Zebra fish, Danio rerio weighing about $200 \pm 50 \mathrm{mg}$ and having a length of about $2.5 \pm 0.5 \mathrm{~cm}$ was collected from private ornamental breeding farm in Chennai and it carefully transported to the laboratory. In the laboratory, the fishes were maintained in plastic troughs containing fresh water at room temperature which was changed every day. All animals were acclimatized to laboratory conditions at least for $24 \mathrm{~h}$.

\section{Experimental design for acute toxicity}

The acute toxicity effect of the $C$. virgo venom was assessed on adult Zebra fish using the Organization for Economic Co-operation and Development (OECD) Guidelines for testing chemicals-fish acute toxicity test. The $\mathrm{LD}_{50}$ was estimated from the graph of percent mortality against dose of venom. All experimental fishes were divided into five groups each comprising of 10 animals as given in Table 1. The single intra peritoneal injection of crude venom was done for acute toxicity using 28 gauge insulin syringe and after injection of crude venom the acute toxicity was assessed for $24 \mathrm{~h}$.

\section{Table 1: Experimental Design.}

\begin{tabular}{c|c|} 
Group 1 : & $\begin{array}{c}\text { Control animals were administered with Tris buffer } \\
\text { saline (TBS) }\end{array}$ \\
\hline Group 2 : & $\begin{array}{c}\text { Animals were administered with venom at } \\
50 \mu \mathrm{g} / \mathrm{kg} \text { body weight }\end{array}$ \\
\hline Group 3 : & $\begin{array}{c}\text { Animals were administered with venom at } \\
75 \mu \mathrm{g} / \mathrm{kg} \text { body weight }\end{array}$ \\
\hline Group 4 : & $\begin{array}{c}\text { Animals were administered with venom at } \\
100 \mu \mathrm{g} / \mathrm{kg} \text { body weight }\end{array}$ \\
\hline Group 5 : & $\begin{array}{c}\text { Animals were administered with venom at } \\
125 \mu \mathrm{g} / \mathrm{kg} \text { body weight }\end{array}$ \\
\hline
\end{tabular}

\section{Behavioral studies and Histological observation}

The Zebra fish behavior was observed after the injection of $C$. virgo venom by the method. ${ }^{15}$ Histological observation for cytological changes in the brain of Zebra fish was carried out using hematoxylin and eosin staining. Zebra fish was anesthetized then it was dried in a paper towel. The head was washed in saline and the skull bones were removed carefully without damaging the brain with the help small spring scissor. The brain was fixed in $10 \%$ buffered formalin and the paraffin blocks were prepared. The $4 \mu \mathrm{m}$ sections were made on clean poly-L-lysin coated glass slide and deparaffinized. The slides were stained with hematoxylin solution and eosin stain.

\section{Statistical analysis}

All the grouped data were significantly evaluated with Graphpad prism (Version 5.0) software to find the variation between the control and experimental animals. Hypothesis testing methods included one way analysis of variance (ANOVA) followed by Tukey's multiple comparison test. The $p$ values of less than 0.05 was considered to indicate statistical significance. All these results were expressed as mean \pm S.D.

\section{RESULTS}

\section{Quantitative and qualitative analysis of crude venom}

The total protein in the collected crude venom was calculated as $7.25 \pm 0.25 \mathrm{mg} / \mathrm{ml}$. Totally thirteen intense bands was observed which includes five slow moving bands, five relatively fast moving bands, two at middle of the gel and three fast moving bands towards the anode region (Figure 1).

\section{Cell viability assay}

The effect of crude venom on A549 was carried out by MTT assay. In order to detect the cytotoxic effect, the different concentration was tested ranging from 


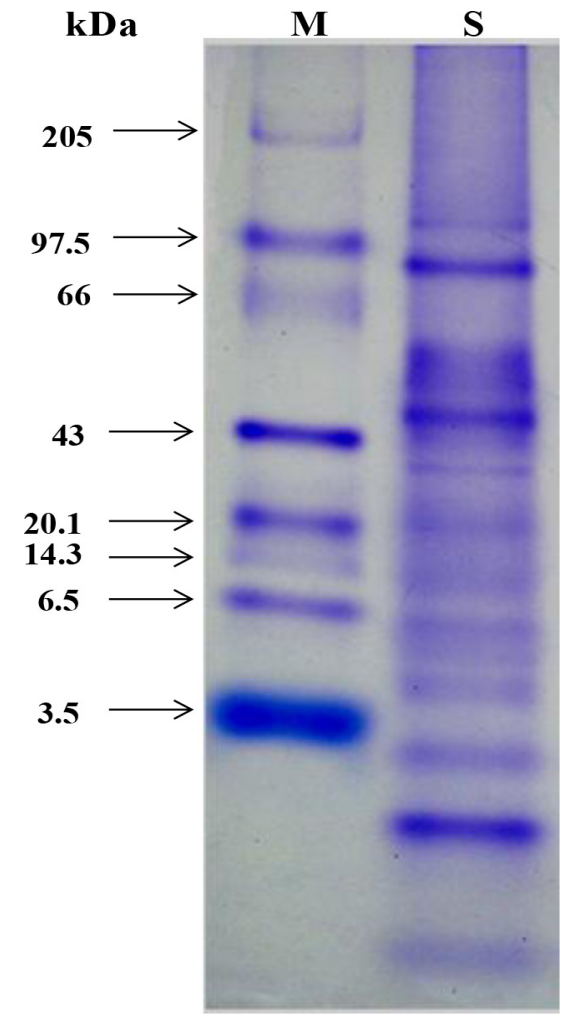

Figure 1: Protein profile of $C$. virgo venom. Lane $M$ - Standard protein marker; Lane S - Crude venom of $C$. virgo

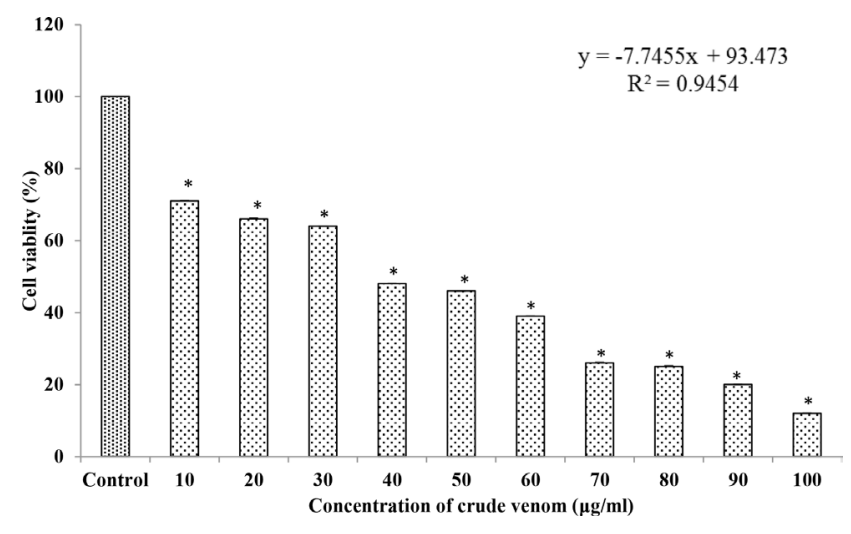

Figure 2: Effect of $C$. virgo crude venom on the cell viability of A549 cells at $24 \mathrm{~h}$. Each point represents the mean \pm SD of three replicates and results are given as statistically significance at $p<0.05^{*}$ between control cells vs crude venom treated cells.

10 to $100 \mu \mathrm{g} / \mathrm{ml}$ for $24 \mathrm{~h}$. In the minimal concentration $(10 \mu \mathrm{g} / \mathrm{ml}) 71 \%$ of cell viability was documented while increasing the concentration toward maximum $100 \mu \mathrm{g} / \mathrm{ml}, 12 \%$ of cell viability was documented when compare to control (Figure 2). Hence it clearly indicates that while increasing the concentration of crude venom the cell viability was decreased and the $\mathrm{IC}_{50}$ was found at a concentration of $74.69 \mu \mathrm{g} / \mathrm{ml}$ and the $R_{2}$ value was found to be 0.945 .

\section{Morphological changes of A549}

The morphological observations of A549, human lung adenocarcinoma cell line were observed under light microscope. The control cells showed normal with epithelial irregular confluent aggregates seen with polygonal shape as well as clear nucleus at the center of the cell (Figure 3A). Upon the treatment of crude venom the polygonal cells were tend to shrink and appeared spherical in shape, loss of colony formation and cytoplasmic blabbing was observed. The cell shrinkage was increased progressively with increase in dose (Figure 3B and C).

\section{Propidium iodide staining}

The venom induces cytotoxicity which was further analyzed using PI staining. The cyoto-nuclear localization of DNA fragmentation was observed in the control and venom treated cells. In the control cell the nucleus were found to be very clear and intact (Figure $4 \mathrm{~A}$ ) whereas upon treatment in $5 \mathrm{~h}$, the nucleus begin to enlarge as well as nuclear condensation was observed. While increasing the concentration $(10$ and $100 \mu \mathrm{g} / \mathrm{ml})$ of the crude venom the no of nuclear fragmentation positively increase which was clearly observed (Figure 4B and $\mathrm{C}$ ).

\section{DNA fragmentation assay}

DNA fragmentation is one of the hallmarks of the apoptosis. The A549 cells were treated with venom for $5 \mathrm{~h}$ at 30 and $80 \mu \mathrm{g} / \mathrm{ml}$ concentrations. The control cells was intact with DNA which appears just below the well, whereas in venom treated at lower concentration the treated cells $(10 \mu \mathrm{g} / \mathrm{ml})$ showed the fragmentation as

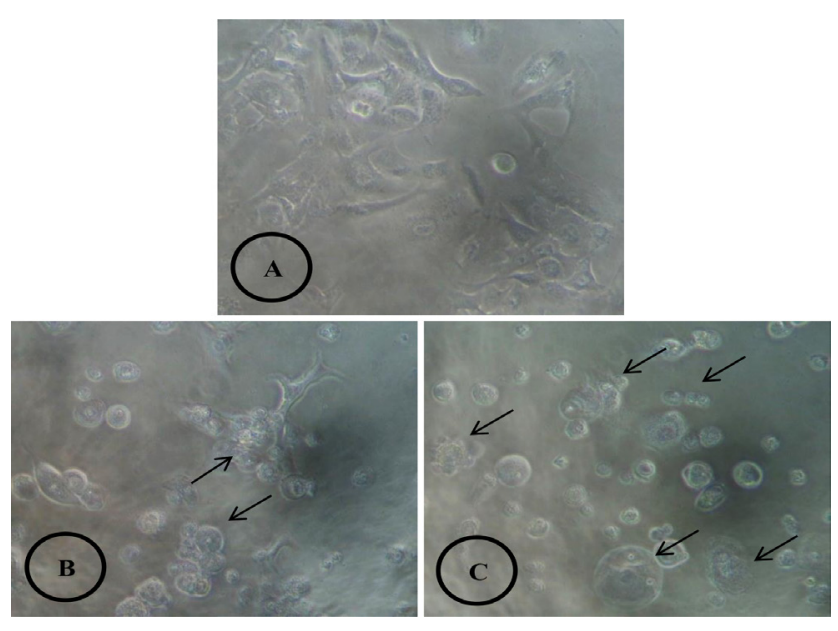

Figure 3: Effect of crude venom on morphology of A549 cells. (A) Control cell; (B) Cells treated with $10 \mu \mathrm{g} / \mathrm{ml}$ of crude venom; (C) Cells treated with $100 \mu \mathrm{g} / \mathrm{ml}$ of crude venom. Scale bar 20x. The arrow mark indicates cell shrinkage, cellular blabbing and loss of colony formation. 


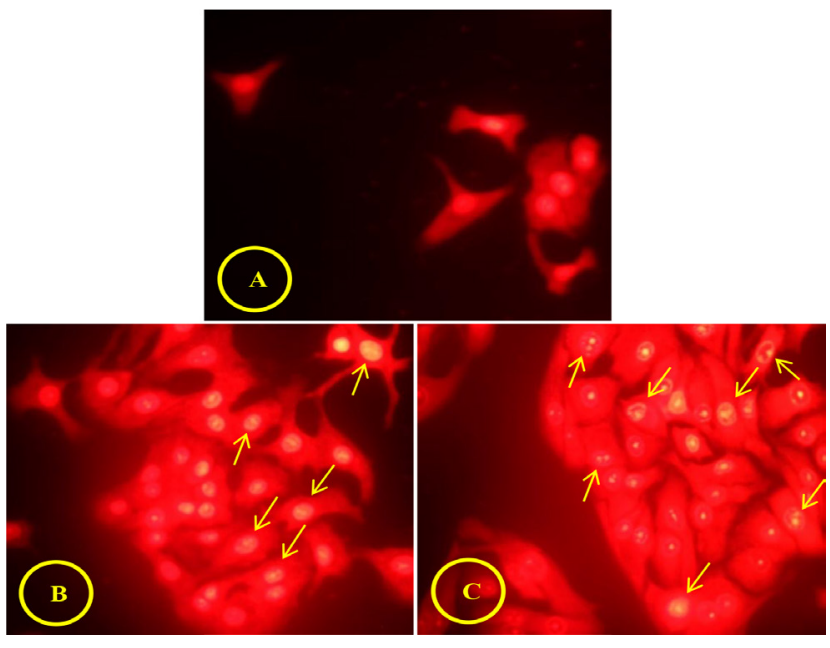

Figure 4: Effect of crude venom on Nuclear morphology of A549 cells. (A) Control cells; (B) Cells treated with $10 \mu \mathrm{g} / \mathrm{ml}$ of crude venom; (C) Cells treated with $100 \mu \mathrm{g} / \mathrm{ml}$ of crude venom. Scales bar $40 x$. The arrow mark indicates damages in the nucleus.

like streaking in the gel and it was increased in the higher concentration $(100 \mu \mathrm{g} / \mathrm{ml})$ (Figure 5).

\section{Acute toxicity}

The acute toxicity effect of crude venom from C. virgo was assessed on adult Zebra fish. The venom samples were administered intraperitoneally injected into Zebra fish with different concentrations (50, 75, 100 and $125 \mu \mathrm{g} / \mathrm{ml}$ ) for $24 \mathrm{~h}$. The percentage of mortality was increased dose dependent manner and the fifty percent mortality $\left(\mathrm{LD}_{50}\right)$ was calculated as $96.939 \mu \mathrm{g} / \mathrm{ml}$ (Figure 6).

\section{Effect of C. virgo venom on Zebra fish behaviors}

The behavioral responses were calculated by affecting locomotory and paralytic activities. The control zebra fish swum for longer time with rapid tail movement. They covered the distance of $0.832 \pm 0.06 \mathrm{Km} / \mathrm{min}$. When administered with $C$. virgo venom the delayed tail movement were observed as well as distance travelled by the fishes were significantly $(p<0.05)$ decreased upon dose dependent manner (Figure 7). Paralysis is a loss of muscle function accompanied by sensory damage as well as motor. In control fishes no paralytic effect was observed. Whereas fishes administered with $C$. virgo venom showed lethargic movements as well as paralytic effects such as floating on the surface of water, settling down at the bottom of trough and erratic swimming behavior was observed. The respiratory movements of the opercula become spasmodic and less frequent manner. The percentage of affected population as well as the duration of recovered time for

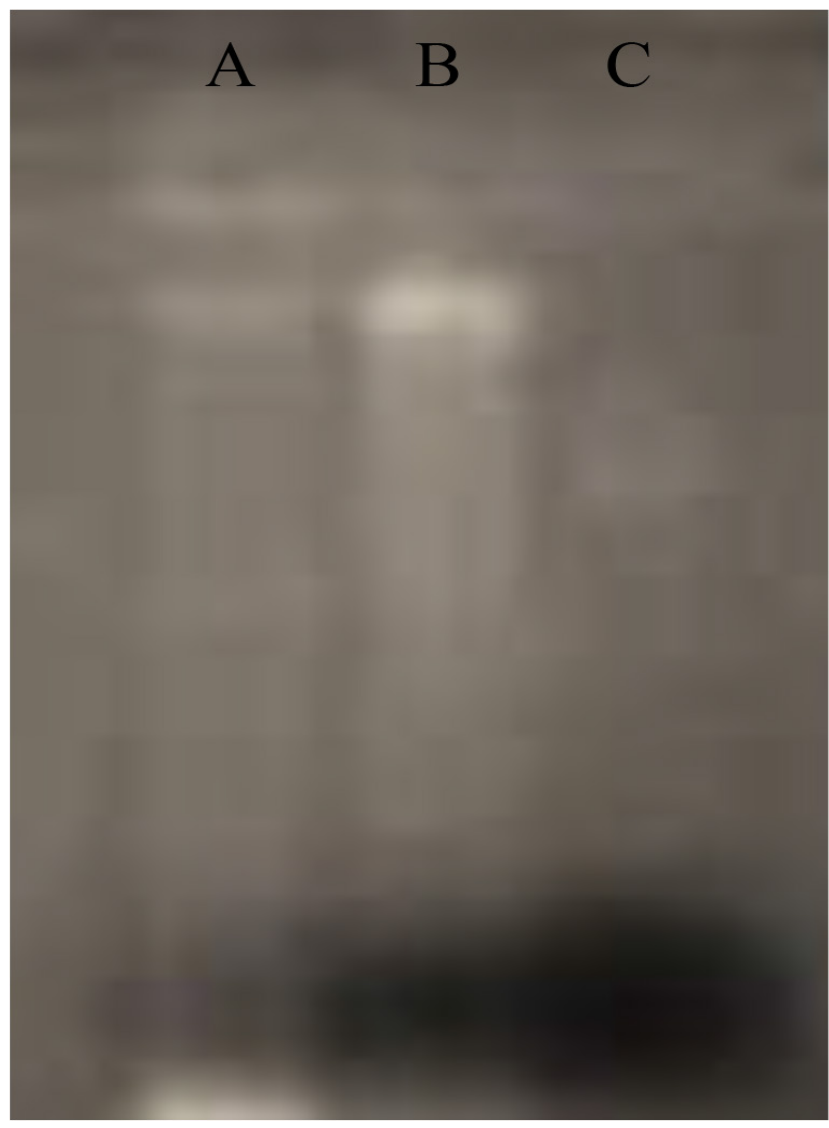

Figure 5: Effect of crude venom induced DNA fragmentation of A549 cells Lane A: Control A549 cell; Lane B: Cells treated with $10 \mu \mathrm{g} / \mathrm{ml}$ of crude venom; Lane C: Cells treated with $100 \mu \mathrm{g} / \mathrm{ml}$ of crude venom.

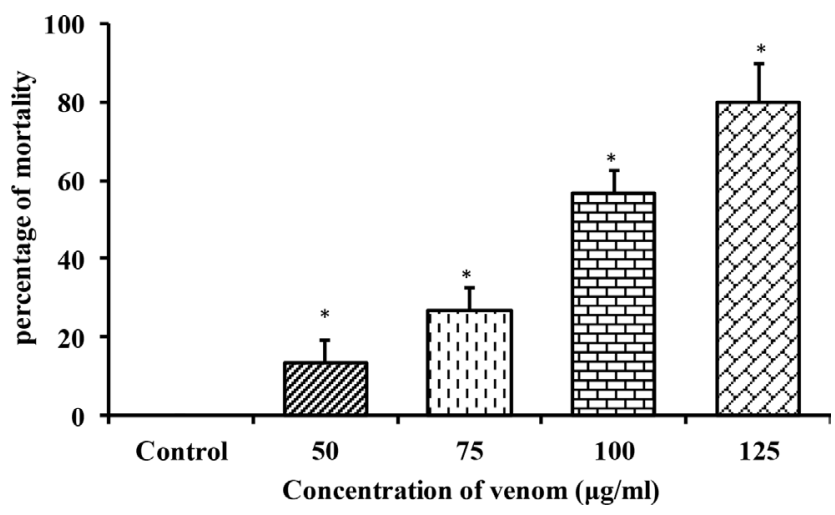

Figure 6: Effect of $C$. virgo venom on percentage of mortality of adult Zebrafish. Each point represents the mean \pm SD of three replicates. Results are given as statistically significance at $p<0.05^{*}$ between control and fishes treated with $C$. virgo venom.

above mentioned anomalies were increased significantly $(p<0.05)$ upon dose dependent manner (Table 2).

\section{Histological observation}

The histological observation was carried out in the brain sections of control and C. virgo venom administered (75 


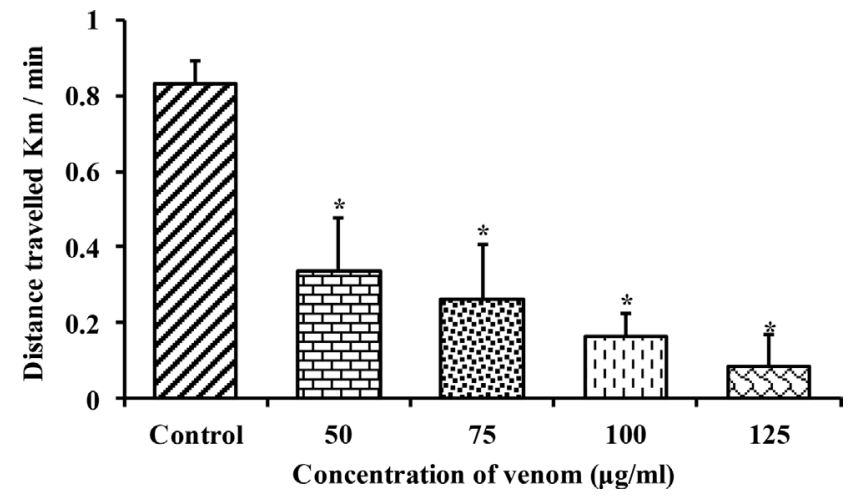

Figure 7: Effect of $C$. virgo venom on locomotory activity of adult zebrafish. Each value is expressed as mean \pm S.D of three independent experiments. Results are given as statistically significance at $p<0.05^{*}$ between control and fishes treated with $C$. virgo venom.

$\mu \mathrm{g} / \mathrm{ml})$ Zebra fishes. The control brain showed normal architecture of nerve fibers as well as never cells in the pallium region. Whereas the fish administered with $C$. virgo venom showed very slight distortion of the nerve fibers as well as slightly elongated and bulged neurons in the pallium region (Figure 8).

\section{DISCUSSION}

Conotoxin primarily consist of proteins. Previously the collection of venom was accomplished by homogenization of venom duct as well venom gland. ${ }^{16}$ The protein content of crude toxin from C. figulinus was 1.9 $\mathrm{mg} / \mathrm{ml}^{17}$ by injection methods. ${ }^{18}$ However these two methods have some disadvantages due to tissue contaminations, occurrence of immature proteins as well as the loss of venom yield. To overcome these disadvantages, the present study aims at collection of venom directly collected from venom duct by squeezing method. The protein present investigation of collected venom was $7.25 \mathrm{mg} / \mathrm{ml}$, which was quantitatively more than venom collected by above mentioned methods. The protein profiles varied depending upon the types of Conus sp. as well as the feeding behavior. ${ }^{19}$ Generally the locomotion of cone snails are lethargic, hence they build up various kinds of feeding strategies to capture their prey. Due to the course of evolution they have developed highly diverse array of protein profiles to paralyze their prey. The venom of cone snails mainly consists of peptides called conotoxins. In general a typical Conus venom contains a minimum of 28 amino acids to $5 \mathrm{kDa}$ peptides. ${ }^{18}$ One of the shortest conopeptides is conophanmus- $\mathrm{V}^{20}$ consisting of 8 amino acids and the longest is con-ikot-ikot having 86 amino acids. ${ }^{21}$ Interestingly, native-PAGE analysis of C. virgo crude venom depicts 15 bands to protein which were

Table 2: Effect of $\mathbf{C}$. virgo venom on the paralytic
activity of adult zebrafish. Each value is expressed
as mean \pm SD for three independent experiments.
Results are given statistical significance at $\boldsymbol{p}<\mathbf{0 . 0 5 ^ { * }}$
between control and fishes treated with C. virgo
venom.
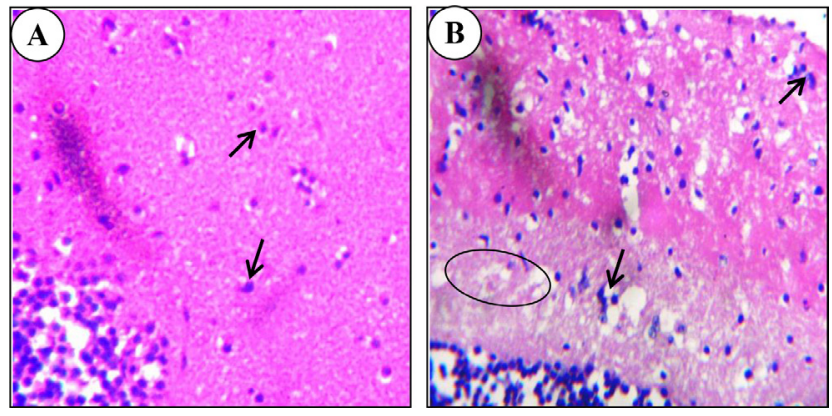

Figure 8: Histological observation of brain tissue sections of Zebrafish viewed under light microscope. (A) brain section of control fish, (B) fish administered with $C$. virgo venom at a concentration of $75 \mu \mathrm{g} / \mathrm{ml}$. Arrows indicate the nerve cells and ellipse indicates the nerve fibers (40x).

observed ranging from below $205 \mathrm{kDa}$ to below 3.5 $\mathrm{kDa}$ (Figure 1). Hence in the present study protein profile reveals that it has both higher and lower molecular weight proteins. The protein profile of $C$. virgo as well as $C$. marmoreus showed multiple protein bands with molecular mass range between below 16 and $250 \mathrm{kDa}$ and C. bteulinus showing a protein profile ranging from $97.4 \mathrm{kDa}$ to above $29 \mathrm{kDa} .{ }^{19}$

The cytotoxic potential of Conus venom has been studied in vitro against lung cancer cell line A549 using MTT assay. It was found that when A549 cells incubated with conus venom for $24 \mathrm{~h}$ it shows a significant dose dependent increase in cell death compared to the control cells. Maximum reduction in the cell viability was observed at $100 \mu \mathrm{g} / \mathrm{ml}$ and the half inhibitory concentration $\left(\mathrm{IC}_{50}\right)$ were found to be at $40 \mu \mathrm{g} / \mathrm{ml}$ (Figure 2). Similarly, previous report stated that the venom extracted from $C$. amadis, has maximum effect 
at $100 \mu \mathrm{g} / \mathrm{ml}$ and the half inhibitory concentration $\left(\mathrm{IC}_{50}\right)$ was $25 \mu \mathrm{g} / \mathrm{ml}$ at a concentration of $45.6 \pm 0.8$ on HEp 2 cell line. ${ }^{23}$ Activity of conopeptides cal14.1a $(27 \mu \mathrm{M})$ against lung cancer cell lines H1299, H1437, H1975 and H661 when evaluated using the MTT assay in all cell lines showed a decrease in cell viability after $24 \mathrm{~h}$, when compared to untreated cells showing survival rate of $30 \% .{ }^{24}$ While in HEK293T cells when treated with primary venom duct cell culture supernatant of C. biliosus species for $48 \mathrm{~h}$ the survival rate of the cells was found to be at $40 \%{ }^{25}$

The cyto-nuclear morphological localization of DNA damage emerged as a new technique to localize the DNA fragmentation up to cellular level, which is a reliable assay to assess the DNA fragmentation. In the present study, nuclear morphology of A549 cells were observed under fluorescence microscope where the control cells showed an intact DNA with round nucleus and cells upon treatment with the crude venom at $5 \mathrm{~h}$ incubation showed changes in nucleus i.e. enlargement of nucleus and condensation of DNA as well as the fragments in both case (Figure 4). Similarly earlier reports showed that DNA fragmentation in Human Embryonic Kidney (293T) cells using DAPI stain at the concentration of $10,20,50 \mu \mathrm{g} / \mathrm{ml}$ respectively for $4 \mathrm{~h} .{ }^{26}$ In MCF7 cells, morphology of the nucleus get disrupted at after 24 and $48 \mathrm{~h}$ of incubation at the concentration of 7.5 and $12.5 \mu \mathrm{g} / \mathrm{ml}$ and synovial fibroblasts cells also showed a very similar nuclear morphology at $10 \mu \mathrm{g} / \mathrm{ml}$ for $24 \mathrm{~h}^{27}$

The DNA fragmentation analysis is one reliable indirect method to assess the apoptosis. In our study the control cells showed the intact DNA and the cells upon treatment with venom at lower concentration of $30 \mu \mathrm{g} /$ $\mathrm{ml}$ showed streaking on the lane but in higher concentration the DNA band appears below that of the other two lanes (Figure 5). Similar results were observed in the earlier reports, ${ }^{27}$ which revealed that the synovial fibroblasts upon treatment with bee venom at $24 \mathrm{~h}$ showed 3 DNA fragmented bands. In Human cervical epidermoid carcinoma Ca Ski cells, the DNA fragments were observed after $48 \mathrm{~h}$ when treated with bee venom. ${ }^{28}$ Hence the DNA fragmentation occurs during the apoptosis, the $C$. califonicus induced apoptosis in lung cancer cells (H1299 and H1437) via Bcl-${ }_{2}$, Bax cascades. ${ }^{29}$ Thus in our investigation, the human lung cancer cell (A549) treated with crude venom of C. virgo showed DNA fragmentation and the nuclear morphology indicating visible damage. This could be due to the induction of apoptosis in human lung cancer cells upon treatment with the venom.
Most of the venomous animals have neurotoxins which are extensive class of chemicals, which can adversely affect the functions of developing as well as mature nerve tissues. ${ }^{30}$ Neurotoxic activity can be characterized by the ability to inhibit neuronal control over ion concentrations across the cell membrane or communication between neurons across a synapse. Local pathology of neurotoxin causes apoptosis and glial cell damage. ${ }^{31}$ The present investigation aimed to attempt the elucidation of systematic adverse effect of Conus virgo venom on adult Zebra fish. Acute toxicity describes the adverse effects of a substance that result either from a single exposure or from multiple exposures in a short period of time not less than $24 \mathrm{~h} .{ }^{32}$ In the present study, different concentrations (50, 75, 100 and $125 \mu \mathrm{g} / \mathrm{ml}$ ) of C. virgo venom was administered to adult Zebra fish, Danio rerio for $24 \mathrm{~h}$ incubation and the $\mathrm{LD}_{50}$ i.e., fifty percent mortality of population was found as 96.939 $\mu \mathrm{g} / \mathrm{ml}$ (Figure 6). These results were similar with previous studies using different experimental animals. The venom of $C$. capitaneus and $C$. episcopates were administered to Zebra fish for assessment acute toxicity. The venom produced lethal effects at high concentrations $(300 \mathrm{mg} / \mathrm{ml})$ within $20-90 \mathrm{~min}^{33}$ The lethality test of C. betulinus venom on brain shrimp (Artemia) showed $\mathrm{LD}_{50}$ at a concentration of $31.5 \mu \mathrm{g} / \mathrm{ml} .^{25}$ The venom of C. musicus depicts the $\mathrm{LD}_{50}$ at a concentration 460.23 $\mu \mathrm{g} / \mathrm{ml}$ against Swiss albino mice model..$^{34}$ Acute toxicity of 31 different nanoparticles with different concentrations was tested on adult Zebra fish for 48 and $96 \mathrm{~h}$. The $\mathrm{LC}_{50}$ values were ranging from $4.2 \mathrm{mg} / \mathrm{l}$ to $1700 \mathrm{mg} / \mathrm{l} .^{35}$ Zebra fishes are advanced freshwater teleosts having basic vertebrate brain organization. The brain of Zebra fish can be divided into five regions (i) telencephalon, (ii) diencephalons, (iii) mesencephalon (iv) metencephalon and (v) myelencephalon. ${ }^{36}$ In mammals, the hippocampus region is involved in cognitive plasticity, whereas in Zebra fish it is absent. However, they have similar region analogues with hippocampus named, lateral pallium. ${ }^{37}$ It involves the functions of olfaction, memory, reproductive behavior, feeding behavior and color vision. ${ }^{38}$ In the present study, the behavioral response was calculated by locomotory and paralytic activity. In the control the zebra fish swam actively and also it covered a distance of $0.832 \pm 0.06 \mathrm{Km} / \mathrm{min}$ (Figure 7). But in the case of C. virgo venom injected fishes showed sluggish movement, as well as the distance travelled by the fishes were significantly decreased upon dose dependent manner. There was no paralytic effect in the control fishes. Whereas in fishes administered with $C$. virgo venom showed lethargic as well as noticeable paralytic effects such as floating on the surface of 
water, settling down in the bottom of trough and erratic and also the respiratory movements of the opercula become spasmodic and less frequent in manner. Similar behavioral changes were recorded in the previous experiment where different concentrations of tetanus toxin on gold fish was tested. Behavioural changes of fishes were noticed about 2 to 3 days after injection of venom. The fish became increasingly lethargic and the respiratory movements of the opercula became spasmodic and less frequent; eventually the animals turned on to their sides and floated immobile. Often sometimes it responded to a bang on the side of the tank by normal or sometimes erratic swimming for a period of a few seconds. About 6-7 days after injection, berating movements ceased and they became completely paralyzed. The heart often continued to beat for few hours, but the animals always died within a day. ${ }^{39}$ This paralytic action is due to rapid or slow firing of nerves, like the sodium channel allowing massively elevated sodium ion flux into the nerve and at the same time blocking the potassium channel, thereby inhibiting the outflow of potassium ions causing an uncontrollable firing of nerves, leading to massive hyper excitability. In fish envenomated by most pisciverous species of Conus this results in rigidity of the fins and total paralysis. ${ }^{40}$

The histology is a technique to examine the tissues in order to study manifestations of disease. In the present study the venom induced alteration was observed, in particularly the pallium and sub-pallium region of brain was focused to analyze the efficacy of C. virgo venom. In the present study fishes were treated with below $\operatorname{LD}_{50}(75 \mu \mathrm{g} / \mathrm{ml})$ and it was taken to histological observation. The control animal showed the normal architecture of pallium and subplaium region with intact nerve cell. Whereas fish administered with C. virgo venom showed distorted pallium (Figure 8). The nerve cell of subpallium region was also slightly distorted. It may be due to over accumulation of various ion channel blockers that blocks the in-flow or out-flow of ions, which blocks the action potential across the synopsis. ${ }^{41}$ This sudden onset may lead to cell bulging or burst which leads to inflammation. ${ }^{42}$ Many reports suggest that the cone snail venom composed of different types of blockers for $\mathrm{Na}^{+}, \mathrm{Ca}^{+}$ and $\mathrm{K}^{+}$channels as well as NMDA and acetyl chlorine receptors. ${ }^{43}$

To summarize, the crude venom of Conus virgo have the ability to inhibit the cell growth of A549 cells and induce the DNA fragmentation in $5 \mathrm{~h}$. The acute toxicity reveals that beyond the optimal dosage, it causes adverse effects like cell bulging and cell aggregation in the brain of Zebra fish which leads to abnormal physiological behavior. The present investigation clearly indicates that the venom of Conus virgo act as a potent neurotoxin against Zebra fish. Further the purification of active toxins can reveal the pharmacological target.

\section{ACKNOWLEDGEMENT}

This study was supported by the UGC non- NET Grand from University Grants Commission, New Delhi, India.

\section{CONFLICT OF INTEREST}

The authors declare no conflict of interest.

\section{ABBREVIATIONS}

DMEM: Dulbecco's modified eagle medium; Trypsin-EDTA: Trypsin-Ethylenediamine tetraacetic acid; FBS: Fetal Bovine Serum; MTT: 3-(4, 5- dimethylthiazol-2yl)-2, 5- diphenyl tetrazolium bromide; DMSO: Dimethyl sulphoxide; NCCS: National Centre for Cell Science; OECD: Organization for Economic Co-operation and Development; DNA: Deoxyribonucleic acid.

\section{REFERENCES}

1. Zufferey KR. Synthesis and improvement of peptides isolated from the venom of cone snails. Thesis. 2007.

2. Kohn AJ. The feeding process in Conus victoriae. The Marine Flora and Fauna of Dampier, Western Australia. Western Australian Museum: Perth. 2003;101-7.

3. Olivera BM. Conus venom peptides: Correlating chemistry and behavior. $J$ Comp Physiol B: Neuroethology, Sensory, Neural and Behavioral Physiology. 1999;185(4):353-9.

4. Olivera BM. EE Just Lecture, 1996: Conus venom peptides, receptor and ion channel targets and drug design: 50 million years of neuropharmacology. Mol Biol Cell. 1997;8(11):2101-9.

5. Olivera BM. Conus venom peptides: reflections from the biology of clades and species. Annu Rev Ecol Evol Syst. 2002; 33(1):25-47.

6. Siegel RL, Miller KD, Jemal A. Cancer statistics, 2016. CA Cancer J. 2016;66(1):7-30.

7. Indian council of medical research. National cancer registry programme. Three year report of population based cancer registries. 2013;2009-11. http:// www.ncroindia.org.

8. Roger S, Rollin J, Barascu A, Besson P, Raynal PI, lochmann S, et al. Voltage-gated sodium channels potentiate the invasive capacities of human non-small-cell lung cancer cell lines. Int J Biochem Cell Biol. 2007;39(4):774-86.

9. Franklin JB, Subramanian KA, Fernando SA, Krishnan KS. Diversity and distribution of conidae from the Tamil Nadu coast of India (Mollusca: Caenogastropoda: Conidae). Zootaxa. 2009;(2250):3-63.

10. Mclntosh JM, Ghomashchi F, Gelb MH, Dooley DJ, Stoehr SJ, Giordani AB, et al. Conodipine-M, a novel phospholipase $\mathrm{A} 2$ isolated from the venom of the marine snail Conus magus. J Biol Chem. 1995;270(8):3518-26.

11. Lowry $\mathrm{OH}$, Rosebrough NJ, Farr AL, Randall RJ. Protein measurement with the Folin phenol reagent. J Biol Chem. 1951;193(1):265-75.

12. Maurer HR, Allen RC. Useful buffer and gel systems for polyacrylamide gel electrophoresis. Clin Chem Lab Med. 1972;10(5):220-5.

13. Mosmann T. Rapid colorimetric assay for cellular growth and survival: Application to proliferation and cytotoxicity assays. J Immunol Methods. 1983;65(1-2):55-63. 
14. Jang MH, Shin MC, Lim S, Han SM, Park HJ, Shin I, Lee JS, et al. Bee venom induces apoptosis and inhibits expression of cyclooxygenase-2 mRNA in human lung cancer cell line NCl-H1299. J Pharmacol Sci. 2003;91(2):95-104.

15. Tierney KB, Singh CR, Ross PS, Kennedy CJ. Relating olfactory neurotoxicity to altered olfactory-mediated behaviors in rainbow trout exposed to three currently-used pesticides. Aquat Toxicol. 2007;81(1):55-64.

16. Kauferstein S, Huys I, Kuch U, Melaun C, Tytgat J, Mebs D. Novel conopeptides of the I-superfamily occur in several clades of cone snails. Toxicon. 2004;44(5):539-48.

17. Saravanan R, Sambasivam S, Shanmugam A, Kumar DS, Vanan T, Nazeer RA. Isolation, purification and biochemical characterization of conotoxin from Conus figulinus Linnaeus (1758). In J Biotech. 2009;8(3):266-71.

18. Möller C, Vanderweit N, Bubis J, Marí F. Comparative analysis of proteases in the injected and dissected venom of cone snail species. Toxicon. 2013;65:59-67.

19. JrDuda TF, Palumbi SR. Evolutionary diversification of multigene families: Allelic selection of toxins in predatory cone snails. Mol Biol Evol. 2000;17(9):1286-93.

20. Pisarewicz K, Mora D, Pflueger FC, Fields GB, Marí F. Polypeptide chains containing d-y-hydroxyvaline. J Am Chem Soc. 2005;127(17):6207-15.

21. Walker CS, Jensen S, Ellison M, Matta JA, Lee WY, Imperial JS, et al. A novel Conus snail polypeptide causes excitotoxicity by blocking desensitization of AMPA receptors. Curr Biol. 2009;19(11):900-8.

22. Sadhasivam G, Muthuvel A, Rajasekaran R, Pachaiyappan A, Thangavel B. Studies on biochemical and biomedical properties of Conus betulinus venom. Asian Pac J Trop Dis. 2014;4(Suppl):102-10

23. Ramesh S, Dilipan E, Mayavu P. Effects of drugs against Antioxidant and Cytotoxic (HEp 2 Cell Line) activity compounds from marine animals Conus amadis venom (GMELIN, J F, 1791). Inter J Phar Pharma Sci. 2014;6(7):63843.

24. Oroz-Parra I, Navarro M, Cervantes-Luevano K, Álvarez-Delgado C, Salvesen G, Sanchez-Campos L, et al. Apoptosis activation in human lung cancer cell lines by a novel synthetic peptide derived from Conus californicus venom. Toxins. 2016;8(2):38.

25. Viswanathan MS, Arularasan S, Patel AK, Shekar MC, Nathani NM, Shah RK, et al. Cytotoxic effect of venom produced in vitro from primary culture of Conus biliosus venom duct cells on HEK 293 t cells. Adv Biol Res. 2015;9(3):133-9.

26. Omran MA, Fabb SA, Dickson G. Biochemical and morphological analysis of cell death induced by Egyptian cobra (Naja haje) venom on cultured cells. J Venom Anim Toxins Incl Trop Dis. 2004;10(3):219-41.

27. Hong SJ, Rim GS, Yang HI, Yin CS, Koh HG, Jang MH, et al. Bee venom induces apoptosis through caspase-3 activation in synovial fibroblasts of patients with rheumatoid arthritis. Toxicon. 2005;46(1):39-45.
28. Ip SW, Wei HC, Lin JP, Kuo HM, Liu KC, Hsu SC, et al. Bee venom induced cell cycle arrest and apoptosis in human cervical epidermoid carcinoma $\mathrm{Ca}$ Ski cells. Anticancer Res. 2008;28(2A):833-42.

29. Oroz-Parra I, Navarro M, Cervantes-Luevano K, Álvarez-Delgado C, Salvesen G, Sanchez-Campos L, et al. Apoptosis activation in human lung cancer cell lines by a novel synthetic peptide derived from Conus californicus venom. Toxins. 2016;8(2):38.

30. Aschner M, Aschner JL. Mercury neurotoxicity: mechanisms of blood-brain barrier transport. Neurosci Biobehav Rev. 1990;14(2):169-76.

31. Bonfoco E, Krainc D, Ankarcrona M, Nicotera P, Lipton SA. Apoptosis and necrosis: two distinct events induced, respectively, by mild and intense insults with N-methyl-D-aspartate or nitric oxide/superoxide in cortical cell cultures. Proc Natl Acad Sci USA. 1995;92(16):7162-6.

32. The MSDS Hyper Glossary: Acute toxicity, Entry last updated: Sunday, July 24, 2016. http://www.ilpi.com/msds/ref/acutetoxicity.html

33. Mebs D, Kauferstein $\mathrm{S}$. Ichthyotoxicity caused by marine cone snail venoms? Toxicon. 2005;46(3):355-6.

34. Balamurgan K, Akalanka D, Raju S, Raju A. Some Neuropharmacological Effects of the Crude Venom Extract of Conus musicus in Mice. East and Central African Journal of Pharmaceutical Sciences. 2007;10(2):28-33.

35. Kovrižnych JA, Sotníková R, Zeljenková D, Rollerová E, Szabová E, Wimmerová S. Acute toxicity of 31 different nanoparticles to Zebra fish (Danio rerio) tested in adulthood and in early life stages-comparative study. Interdiscip Toxicol. 2013;6(2):67-73.

36. Wullimann MF, Rupp H, Reichert H. The Zebra fish brain: A neuroanatomical comparison with the goldfish. Anat Embryol. 1996;194(2):87-203.

37. Rodríguez F, López JC, Vargas JP, Broglio C, Gómez Y, Salas C. Spatial memory and hippocampal pallium through vertebrate evolution: insights from reptiles and teleost fish. Brain Res Bull. 2002;57(3-4):499-503.

38. Roberts RJ, Ellis AE. The anatomy and physiology of teleosts, In Fish Pathology, $3^{\text {rd }}$ ed., Philadelphia, USA: W. B. Saunders.P. 2001;12-54.

39. Diamond J, Mellanby J. The effect of tetanus toxin in the goldfish. J Physiol. 1971;215(3):727-41.

40. Imperial JS, Silverton N, Olivera BM, Bandyopadhyay PK, Sporning A, Ferber $\mathrm{M}$, et al. Using chemistry to reconstruct evolution: on the origins of fish-hunting in venomous cone snails. Proc Am Philos Soc. 2007;151(2):185-200.

41. Terlau H, Olivera BM. Conus venoms: A rich source of novel ion channeltargeted peptides. Physiol Rev. 2004;84(1):41-68.

42. Vetter I, Lewis RJ. Therapeutic potential of cone snail venom peptides (conopeptides). Curr Top Med Chem. 2012;12(14):1546-52.

43. Shon KJ, Stocker M, Terlau H, Stühmer W, Jacobsen R, Walker C, et al. K-Conotoxin Pviia Is a Peptide Inhibiting the Shaker K+ Channel. JBiol Chem. 1998;273(1):33-8.

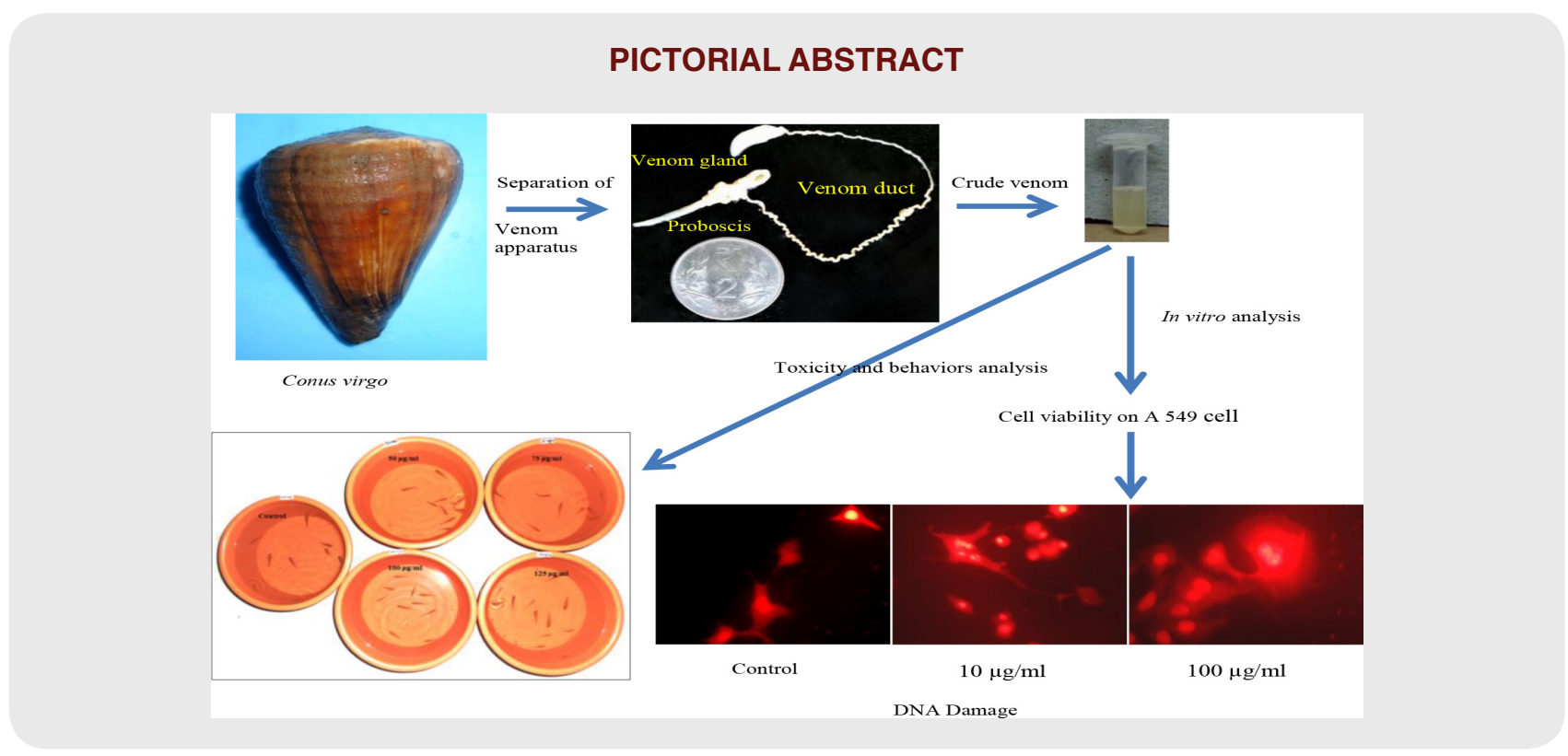




\section{SUMMARY}

- The antiproliferative effect of crude venom of $C$. virgo treated against A549 cells. The result clearly emphasizes, decrease in the cell viability at different concentration (10 to $100 \mu \mathrm{g} / \mathrm{ml}$ ). The $\mathrm{IC}_{50}$ was found at $74.69 \mu \mathrm{g} / \mathrm{ml}$.

- The effect of crude venom on cell morphology was observed, while increasing the concentration of venom the cells lost their morphological integrity. The cyto-localization of nuclear morphology and DNA fragmentation assay revealed the induction of apoptotic cell death in A549 cells at 5 hours.

- The acute toxicity assessment was done at different concentration such as $50,75,100,125 \mu \mathrm{g} /$ $\mathrm{ml}$ of venom on adult zebrfish according to the OECD guidelines. The $\mathrm{LD}_{50}$ value was calculated as $96.393 \mu \mathrm{g} / \mathrm{ml}$.
- The behavioral studies such as locomotory and paralytic activity was monitored. When zebrafish administered with $C$. virgo venom the movement as well as the covered distance travelled by the fishes were significantly decreased upon dose dependent manner. Similarly, the paralytic effects particularly erratic swimming behavior as well as the percentage of affected population along with the duration of recovered time were increased significantly upon dose dependent manner.

- Histological observations of brain tissue sections were carried out in control and venom treated fishes. The control brain showed normal architecture of nerve fibers as well as never cells in the pallium region. Whereas the fish administered with C. virgo venom showed very slight distortion of the nerve fibers as well as slightly elongated and bulged neurons in the pallium region.

\section{About Authors}

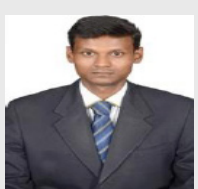

Dhana Sekaran Ganesan, Research Scholar, Department of Zoology, University of Madras Guindy Campus, Chennai, Tamil Nadu, India.

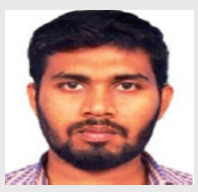

Mohamed Asik Raj Mohamed, M.Sc, Department of Zoology, University of Madras, Guindy Campus, Chennai, Tamil Nadu, India.

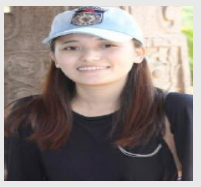

Pema Lhanzin, M.Sc, Department of Zoology, University of Madras, Guindy Campus, Chennai, Tamil Nadu, India.

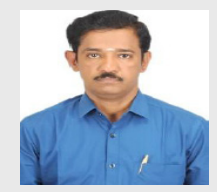

Kathirvel Neelan, Research Scholar (Part time), Department of Zoology, University of Madras, Guindy Campus, Chennai, Tamil Nadu, India.

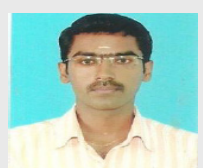

Lakshmanan Vadakkuvaselvi, M.Sc, Department of Zoology; University of Madras, Guindy Campus, Chennai, Tamil Nadu, India.

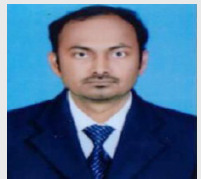

Dr. Sellamuthu Subramani, Research Scientist, NisSCELL- Nichi Asia Centre for stem cell and Regenerative Medicine, Malaysia.

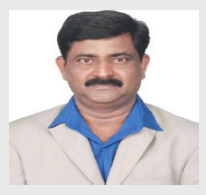

Dr. Arulvasu Chinnasamy, Assistant Professor, Department of Zoology, University of Madras, Guindy Campus, Chennai, Tamil Nadu, India.

Cite this article: Ganesan DS, Mohamed MAR, Lhanzin P, Vadakkuvaselvi L, Subramani S, Chinnasamy A. Antiproliferative Effect of Crude Venom from Conus virgo on Human Lung Cancer Cell Line and Toxicity Assessment on Adult Zebra Fish (Danio rerio). Indian J of Pharmaceutical Education and Research. 2020;54(1):85-94. 